\title{
A Paraboarmia viertlii (Bohatsch, 1893) bionómiája, elterjedése Magyarországon és Európában (Lepidoptera: Geometridae)
}

Bionomy and Distribution of Paraboarmia viertlii (Bohatsch, 1893) in Hungary and Europe (Lepidoptera: Geometridae)

\section{Fazekas Imre}

Citation. Fazekas I. 2021: A Paraboarmia viertlii (Bohatsch, 1893) bionómiája, elterjedése Magyarországon és Európában (Lepidoptera: Geometridae) | Bionomy and Distribution of Paraboarmia viertlii (Bohatsch, 1893) in Hungary and Europe (Lepidoptera: Geometridae). - Lepidopterologica Hungarica 17(1): 61-72.

Abstract. New information of Paraboarmia viertlii (Bohatsch, 1893) about the biology and geographical distribution of the species. The author examined the Hungarian and European collections and reviewed the literary sources. A provisional new distribution map of $P$. viertlii has been completed. It presents the preferred habitats of the species. The species is in strong regression in Hungary and Europe, and the population is endangered.

Keywords. Lepidoptera, Geometridae, Paraboarmia viertlii, bionomy, distribution, Hungary, Europe

Author's address. Fazekas Imre | Pannon Intézet/Pannon Institute | 7635 Pécs, Magaslati út 24. | Hungary | E-mail: fazekas@lepidoptera.hu

\section{Summary}

Paraboarmia viertlii (Bohatsch, 1893) was described from South Hungary. Type locality: Pécs ("Fünfkirchen"), Mecsek Mountains. On the southern side of the mountains there is a huge city Pécs, which is more than 2,000 years old, constantly expanding. The new neighbourhoods partially occupied the type of locality of the species. The population of the original sub-Mediterranean oaks is gradually declining, disappearing or changing in many places. In place of the oaks, black pine (Pinus nigra) was planted, but this species of pine is destroyed by diseases. Based on a 50-year study, it can be concluded that $P$. viertlii is in strong regression in the mountains, and the population is endangered. There are years when no specimen can be found.

So far, $P$. viertlii has not been studied in detail in Hungary. There was a very incomplete knowledge about the biology and geographical distribution of the species. The author examined the Hungarian collections and reviewed the literary sources.

A provisional distribution map of $P$. viertlii has been completed. The distribution pattern has been enriched with a lot of new knowledge, as many have described before.

It is shown that the species lives mainly in the limestone and dolomite Hungarian mid-mountains, but it also has local and strong populations in the sandy oak forests of the Great Plain. The most important plain habitat types in Hungary are as follows: open steppe oak forests on sand (Natura 2000: 9110, Euro-Siberian steppic woods with Quercus spp.); closed lowland steppe oak forests); lowland oak-hornbeam forests (Natura 2000: 91F0); and Convallario-Quercetum Kevey, 2008 item ConvallarioQuercetum roboris Soó, 1939.

The hitherto known and preferred mid-mountain habitats are sessile oak-hornbeam forests (Natura 2000: 91G0); beech forests (Natura 2000: 9130, for example Mecsek Mountains, altitude 300-400 m); closed thermophilous Quercus pubescens forests (Natura 2000: 91H0); Quercus pubescens scrub; Quercus cerris-Quercus petraea for- 
ests (Natura 2000: 91M0); closed mixed steppe oak forests on loess (Natura 2000: 9110).

A very interesting and relict habitat known at Drava River of "Juniper Woodland" with alluvial ash-alder forest and Quercus cerris-Quercus petraea forests in the higher protrusions.

The species is extremely local to the north and west of the borders of Hungary, in Austria, Slovakia, the Czech Republic, Slovenia, Italy and France. Isolation is strong and geographical distances are long. This is typical of the entire range of the species, including the Balkans and West Asia.

$P$. viertlii was known from Croatian Istria. According to Habeler (2011), the first reported occurrence of the species in Slovenia was at light traps near Podgorje in the Karst. It has a local distribution in Slovenia, where it occurs in the thermophile oak forest habitats on the limestone (Slovenian Karst), like hop-hornbeam woods (habitat code type 41.81). These are open forest habitats, usually with dry meadows on the stony soil, otherwise not very productive. It has been discovered in Slovenia only recently. It flies late at night, usually coming to light after midnight or even later, one of the reasons we do not have so much data. The moths fly from mid-June till mid-July (Gomboc pers. comm.).

In the Czech Republic (South Moravia), the species was first collected in 1969 near Valtice, which is the northernmost known site in Europe. In mid-July, 5 males flew to the light. Eight years later, the species was found again in the same place (Krampl et al. 1980). No other records are known.

There are insufficient data on the sporadic Slovakian populations and the size of the populations.

In summary, the bionomy and geographical distribution of $P$. viertlii are only partially known and further research is needed. It is especially important to explore the different localities and to assess the size of the populations. It is important to find out which are the preferred habitats and host plants.

\section{Bevezetés - Introduction}

Bohatsch (1893) szerint „Mein Freund, Adalbet Viertl, k. k. Kapitän In Fünfkirchen, unserem unermüdlichen Sammler, haben wir bereits gehört zu Ungarn mit vielen neuen Entdeckungen, hatte im Vorjahr Glück mit einer neuen Boarmia, 7 Exemplare muss aus Raupen aufgezogen werden, die im Mai 1882 erworben wurden, Quercus klopfte, ignorierte es aber leider.” „... Schließlich danke ich Herrn Viertl für das mir geschenkte Vertrauen und spreche die Hoffnung aus, dass derselbe heuer wohl Gelegenheit finden dürfte, die Raupenbeschreibung nachzutragen."

Abafi Aigner (1907) csak két előfordulását közölte: Budapest, Pécs. A fajt a képtáblán nem mutatta be.

Gyulai et al. (1974) szerint: „Boarmia viertlii BOHATSCH. Igen sajátos, szaggatott elterjedésű faj. Sokáig - éppen úgy, mint az Orthosia schmidtii-t - Kárpát-medencei endemizmusnak tartották és csak a legutóbbi években került elő Dél-Franciaországból (J. WOLFSBERGER szóbeli közlése) illetve Kis-Ázsiából (Kizil-Sahaman, Ankara mellett, leg. R. PINKER, revid. VARGA Z.). Valószínüleg mindkét forma a Kárpátmedenceitől (Várgesztes, Budakeszi, Felsőtárkány: fénycsapdák ill. Borosjenő, Mecsekhegység) eltérő alfajt képvisel. Új hazai adata: Bükk-hegység, Sikfőkút, 1972-73. VI. eleje, több példány."

Balogh (1978) számos lelöhely adatot közölt: "Boarmia viertlii Bohatsch. A lepkét VIERTL Pécsett gyüjtötte, amelyet BOHATSCH 1883-ban írt le. Lelőhelyei: Fenyőfö (Sch); Simontornya, 1933. (Pi); Isaszeg, 1951. (I); Uzsa, 1952. VII. 22. (B); Bükk hg.: 


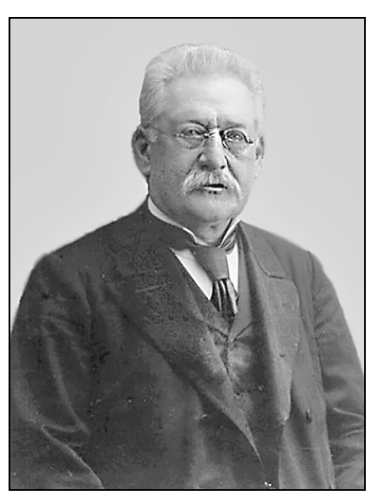

1

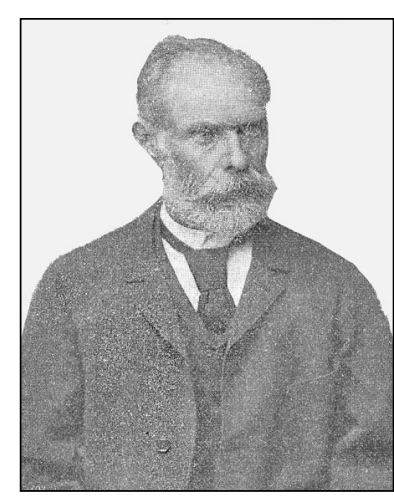

2

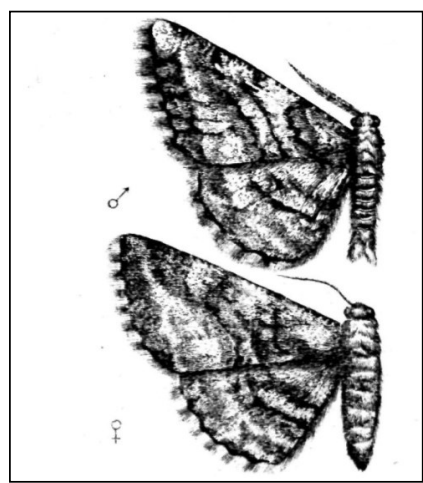

3

1-2 ábra | Figs. 1-2. 1. Otto Bohatsch (1843-1912), 2. Adalbert Viertl (1831-1900), 3. A „Boarmia Viertlii” eredeti ábrázolása | original representation of „Boarmia Viertlii" (Bohatsch 1883)

Szentlélek, 1952. VII. 22. (Ki), Baktai-tó, 1962. VII. 8. (J), Felsőtárkány (fcs), Sikfökút, 1972-74. VII. (Gyulai P, Uh.VZ); Budakeszi, 1963. VII. 11., 19. (fcs); Vértes hg. (Köhányáspuszta), 1961. VII. 11. (G); Cserépfalu, 1963. VII. 10. (J); Csákvár, 1967. VII. 1.; Várgesztes, 1965. VII. (fcs); Zamárdi (Ré);”

A faj első magyarországi elterjedési térképét és ivarszervi vizsgálatát a püspökszentlászlói arborétumban végzett vizsgálataim alapján készítettem el (Fazekas 1979: pp. 76-78, 9-10. ábra; gen. prep Fazekas I. No. 1092).

Vojnits (1980) faunafüzetében a következőket írta: „A rendkívül szük elterjedésü fajt elsősorban a Kárpát-medencében, valamint a Taurus-hegységben találták. A magyarországi populációk megegyeznek a törzsalakkal. A Dunántúl néhány pontján és az Alföldön (Ágasegyháza) gyüjtötték száraz tölgyesekben; ritka. Egyetlen nemzedéke VI -VII-ben repül. Hernyója tölgyön él; a faj életmódja még alig ismert.” A szerző nem pontosította, hogy a fajt Pécsről írták le, pedig ez egy magyar faunamúben, nem csak taxonómiailag, hanem tudománytörténetiéig is fontos. Az, hogy hernyója „tölgyön él” nem megfelelő információ, ugyanis hazánkban egy tucatnál több Quercus spp. él (vö. Király (2009). A magyar faunafüzet nem tesz említést a faj balkáni, olaszországi és franciaországi elterjedéséről sem. A magyar „Vörös könyv”-ben sem találunk a fajra vonatkozó utalást (Rakonczay 1989).

Forster \& Wohlfahrt (1981) közép-európai könyvükben meglepően szükszavúan, csupán két sort írtak a fajról: „Lokal und selten in Ungarn und Tessin. Flugzeit Juni und Juli. Raupe vom Spätsommer an überwinternd bis Mai auf Eiche.” A könyv 23. képtábláján (Fig. 13.) egy világos alapszínű hím példányt ábrázoltak: „Südungarn, Borosjanoe, 5.7.1931”. Borosjenő (Ineu) romániai lelőhely.

Pastorális \& Szeőke (2018) további lelőhelyröl tudósítottak: Gánt (Bagoly-hegy).

\section{Anyag és módszerek - Material and methods}

Vizsgálati anyag a következő gyüjteményekben található:

The material examined is in the following collections:

JPM - Janus Pannonius Múzeum (Pécs)

MTM - Magyar Természettudományi Múzeum (Budapest) 
KTGY - Komlói Helytörténeti és Természettudományi Gyüjtemény (Komló)

MNB - Museum für Naturkunde (Berlin)

PI - Pannon Intézet (Pécs)

RRM - Rippl Rónai Múzeum (Kaposvár)

ZSM - Zoologische Staatssammlung (München)

A tanulmány a szerző 50 éven át végzett éjszakai lámpázásos (160 Wattos kevertfényü HMLI izzók) és fénycsapdás (125 Wattos higanygőz lámpák (Fazekas 1975) gyüjtéseit, illetve bionómiai megfigyeléseinek adatait dolgozza fel. Az elterjedési térkép elkészítésénél felhasználta a Magyar Természettudományi Múzeumban őrzött példányokat is. Az irodalmi adatok közül csak a hivatkozásokban publikált lelőhelyek kerültek az elterjedési térképre. A kopott, töredezett fénycsapda példányok genitália vizsgálatát Wanke \& Rajaei (2018) egyszerü és gyors módszerével végeztem.

Az imágók képei Sony DSC-H100v fényképezőgéppel és Zeiss sztereó mikroszkópra szerelt BMS tCam 3,0 MP digitális kamerával készültek, a ScopePhoto 3.0.12 szoftver segítségével. A genitália fotókat a Scopium XSP-151-T-Led biológia mikroszkóppal és a számítógéphez csatlakoztatott MicroQ 3.0 MP digitális kamerával készítettem 20x-os és 50x-es nagyítással. Az így elkészített habitus és preparátum fotókat a Corel Draw/Paint és Photoshop programokkal elemeztem.

\section{Eredmények - Results}

Paraboarmia Krampl, 1994 (Geometridae)

Original reference: Paraboarmia Krampl, 1994, Folia Heydrovskyana 2 (7): 89. Type species: Boarmia viertlii Bohatsch, 1883, by original designation.

Paraboarmia viertlii (Bohatsch, 1883)

Boarmia Viertlii Bohatsch, 1883, Wiener Entomologische Zeitung 2(5): 111-114. Locus typicus: „Ungarn, Fünfkirchen" (= Pécs).

Irodalom - Reference: Abafi Aigner (1907), Ábrahám \& Uherkovich (2000), Balogh (1978), Fazekas (1979, 2005, 2006), Forster \& Wohlfahrt (1981), Gyulai et al. (1974), Habeler (2011), Horváth (2016), Kovács (1953), Krampl (1994), Krampl et al. (1980), Laštuvka \& Liška (2011), Müller et al. (2019), Pastorális \& Szeőke (2018), Reiprich \& Okali (1989), Rézbányai (1972), Štanta \& Zadrgal (2016), Varga (2010), Viertl (1898), Vojnits (1980), Vojnits et al. (1993).

Diagnózis - Diagnosis. Az elülső szárnyak fesztávolsága: đ̋đ 23-33 mm, 우 30-35 mm, alapszínük szürkésbarna. A belső és külső keresztsávok sötétbarnák vagy szürkésbarnák, olykor feketék. A középtér árnyéksávja enyhén ívelt, folytonos, esetenként szakadozott. A szegélytér hullámvonala világos, kívül árnyékolt. A hátulsó szárny középfoltja sötét, belül nem világos, egy L-alakú keresztsávval. A középtér keresztsávja sötét, keskeny, a szegélytér keresztsávja ívekből áll.

Változékonyság - Variability. Ismertek melanisztikus példányok is, amelyeknél a keresztsávok alig különülnek el. Sokfelé előfordulnak olyan szárnymintázatok, ahol az alapszín hamuszürke. Igen szórványosan előkerültek vörhenyesbarna, sőt igen világos példányok is.

đ̧ genitália - genitalia. Uncus majdnem lapos végű, gnathos kerekebb. Valva nyújtott, széles, egyszerü. A csúcs lekerekített, a costa és az alap gyengén szklerotizált. Középen egy kis kúpszerü gerinc tüskecsoporttal. A juxta háromszög alakú, csúcsa kerek. Aedeagus hengeres, egyenes, három különböző hosszúságú cornutus-al és gyengén szklerotizált granulált résszel. Megvizsgált példány 17 ex; Mecsek, Bakony. Terminológia: Hausmann (2001). 


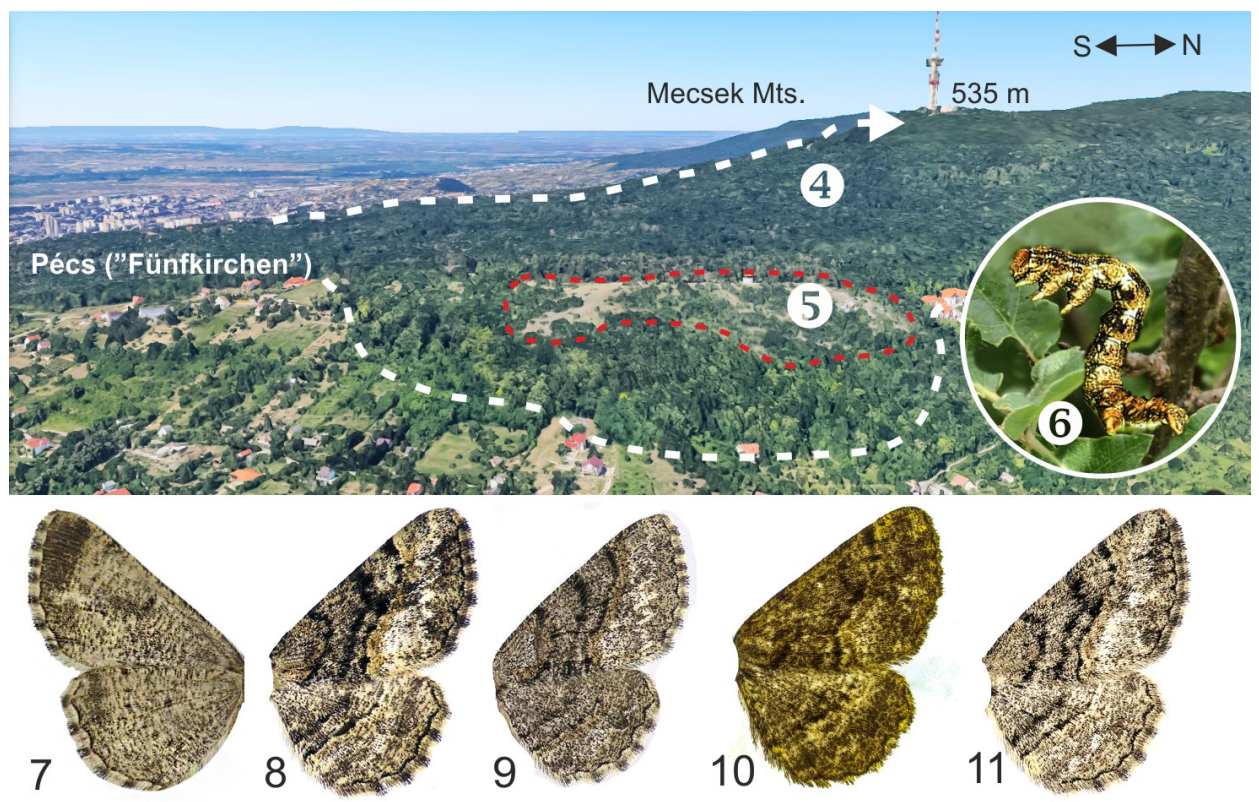

4-11. ábra. A Paraboarmia viertlii típuslelőhelyének recens tájmintázata (Pécs, Mecsekoldal): 4. mecseki karsztbokorerdő (Inulo spiraeifoliae-Quercetum pubescentis), feketefenyvesekkel, 5. dolomit sziklagyepek (Dömörkapu), 6. lárva; 7-11. P viertlii szárny mintázatok a Mecsekből; 7. a szárnyak fonákja, 8. + , Misina, 9. + , Tubes, 10. , Püspökszentlászló, 11. ㅇ, Dömörkapu.

Figures 4-11. Type locality of Paraboarmia viertlii Mecsek Mountains (Pécs, „Fünfkirchen”): 4. vegetation of Inulo spiraeifoliae-Quercetum pubescentis, 5. calcareous open rocky gasslands, 6. larva on Quercus pubescens, 7-11. wing patterns of Mecsek Mountains (7. underside)

genitália - genitalia. Papillae anales hártyás, puha, enyhén lekerekített. Az apophyses posteriores nagyon hosszú (átlagosan $3,1 \mathrm{~mm}$ ), az apophyses anteriores rövidebb (átlagosan 1,4 mm), mindkettő a csúcsán spatulált. A ductus bursae rövid, szklerotizált. A corpus bursae hártyás, elülső szélén kissé széthúzott, lekerekített. Signum közepes méretü, csillag alakú. Lamella antevaginalis kicsi és keskeny, kúposan szárnyszerü. A lamella postvaginalis egy szklerotizált háromszög alakú lemez, elöl kétágú. Megvizsgált példány 3 ex; Mecsek. Terminológia: Hausmann (2001).

\section{Bionómia - Bionomics}

Repülési idő - Flight period. Univoltin faj; az imágók június elejétől augusztus elejéig késő éjszaka repülnek különböző tölgyerdő társulásokban, többnyire éjfél után aktívak, fényre folyamatosan repülnek. Preferálják az erdei tisztásokat, az erdőszegélyeket, a sziklagyep-karsztbokorerdő mozaikokat.

Lárva - Larva. A lárvák augusztustól az ősz végig tölgyfajok leveleivel táplálkoznak (Quercus cerris L., Qu. robur L., Qu. petraea Liebl., Qu. daleshampii Ten., Qu. pubescens Willd., Qu. virgiliana Ten.), ezt követően áttelelnek. Májusban, föként a le- 

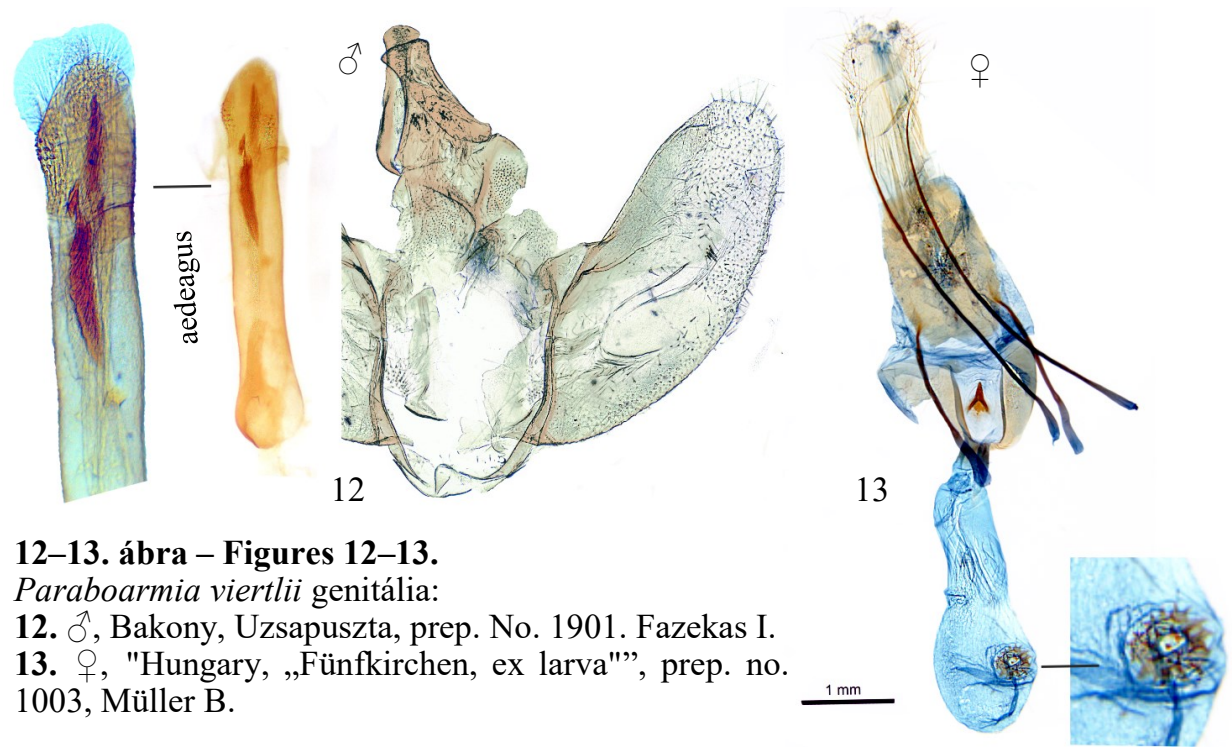

12-13. ábra - Figures 12-13.

Paraboarmia viertlii genitália:

12. $\widehat{O}^{\lambda}$, Bakony, Uzsapuszta, prep. No. 1901. Fazekas I.

13. + , "Hungary, „Fünfkirchen, ex larva"”, prep. no. 1003, Müller B.

veleken, szövedékben bábozódnak. A báb 11-13 mm hosszú, átmérője 3-32 mm. A cremaster rövid és villás. Viertl (1898) eredeti hernyó leírása a XIX. századból:

A Boarmia Viertlii-nak, melyet 1883-ban Pécsett fedeztem fél, már nehány év óta nem találtam hernyóját, minthogy az pedig mind ez ideig leírva nincsen, a Nemzeti Muzeumnak ajándékoztam példányok után adom leirását. Kifújva $3 \mathrm{~cm}$. hosszú, alakra nézve a Consortaritu-ére, szinre pedig az Abirturiuére emlékeztet. Feje vöröses, finoman szörzött, arczban két függöleges, világosabb sávval. Teste rozsda-barna (vöröses-barna) sötétbarna hátsávval, s ugyanoly melléksávokkal, melyek azonban mind (kivált az útóbbiak) igen homályosak, és csak az elsö szelvényeken tisztábban láthatók. Minden szelvényen oldalt világosabb (fehéres) folt van. Az elsö szelvény s a torpaizs fehéres, az utolsó szelvény sötétebb-barna mint a testszin, két erősebb bütyökkel. A szemölcsek kicsinyek, világosabbak dz alapszínnél, mindegyiken nehány szöröcske. Az 5., 6. és 7. szelvényen oldalt egy-egy nagyobb, kissé hegyes bütyökkel, melyik épen oly sötét-barnák, mint ez egész szelvények, melyek a háton $2-2$ fehéres pontot láttatnak. Ezek a bütykök a szintén valamivel sötétebb s oldalt kissé kiálló 8., 9. és 10 . szelvényen csak jelezve vannak. Tulajdonképeni stigmavonal hiányzik; a stigmák kerekded alakúak, fehẻresek, fekete kerettel. A has s a lábak az alapszínnél valamivel világosabb színüek. 
Habitat - Habitat. Xerothermophil faj. A Dunántúl domb- és hegyvidékein, az Északi-középhegységben föként a következő élőhelytípusokat preferálja: molyhos tölgyes bokorerdők (Natura 2000: 91H0), cseres-kocsánytalan tölgyesek (Natura 200: 91M0), hegylábi zárt erdőssztyep lösztölgyesek (Natura 2000: 91I0), mész- és melegkedvelő tölgyesek (Natura 2000: 91H0), gyertyános-kocsánytalan tölgyesek (Natura 2000: 91G0), bükk elegyes tölgyesek és törmeléklejtő erdők (Natura 2000: 9180, pl. Mecsek, Villányi-h.), tölgyes jellegü sziklaerdők és tetőerdők (Natura 2000: 9150).

Mecsek-Villányi-hegység: A típuslelőhely (Dömörkapu, Misina, Tettye, Tubes) mecseki karsztbokorerdő (Inulo spiraeifoliae-Quercetum pubescentis), mecseki mészkedvelő olasz tölgyes (Tamo-Quercetum virgilianae) valamint mecseki sisakvirágos tetőerdő (Aconito anthorae-Fraxinetum orni) komplexek területére esik.

Kelet-Belső Somogy: Darány, borókás, 1980.VI.22. leg. Uherkovich Á. (in coll. JPM, Pécs). Juhász (1983) szerint a területen [Barcsi Ösborókás Tájvédelmi Körzet], a Rigóc-patak mentén égerligetek és keményfaligetek találhatók, míg a magasabb részeken $(150 \mathrm{~m})$ cseres-tölgyes erdők maradványfoltjai vannak. Kiirtásuk helyét savanyú homokpusztagyepek, borókás-nyíresek, ültetett erdei fenyvesek és akácosok foglalták el.

Alpokalja, Fertőmelléki-dombság: Alpokalji molyhos tölgyes (Euphorbio-Quercetum), Szárhalmi erdő (Borhidi 2003, Borhidi et al. 2012).

Duna-Tisza köze: Kecskemét, (Nyír), Kunfehértó (Hármashatár-erdő), Kunpeszér (leg. Máté A.); alföldi zárt kocsányos tölgyes (Natura 2000: 9110); nyílt homoki tölgyes (Natura 2000: 9110) [vö.: Bölöni et al. 2011, ÁNÉR].

Nyírség: Nyíregyháza (Baktai-erdő), tszfm. 117-150 m: ÁNÉR 2011, K1a - gyertyános-kocsányos tölgyes (Natura 2000: 91F0. Ez a társulás a homoki gyertyánostölgyes a klímazónáján kívül fordul elö, ezért a tölgyes zónán belüli megjelenése extrazonálisnak tekinthető, amely a talajvíz által kissé befolyásolt üde mikroklímának köszönhető (Kevey et al. 2017, Zagyvai \& Bartha 2015). Az állományban feltünőek az egyes szubmontán elemek, amelyek az Alföldön általában ritkák. E növények valószínủleg a hüvösebb, csapadékosabb és kiegyenlítettebb klímájú Bükk I. kor (i.e. 2500-tól i.e. 800-ig) maradványfajai. Valószínűleg ennek a posztglaciális kornak a maradványfaja a Nyírségben a Paraboarmia viertlii is, amely napjainkra eltünt a térségből.

Nyíregyháza (Sóstói-erdő): Kevey (kiadatlan kézirat, pers. comm.) hat cönológiai felvétele alapján gyöngyvirágos tölgyes (Convallario-Quercetum Kevey 2008) [nyírségi gyöngyvirágos tölgyes - Convallario-Quercetum roboris Soó (1939) 1957], számos. Kevey sem a Sóstói- sem pedig Baktai-erdőben nem talált molyhos tölgyet. A Sóstói-erdőből hiányzik a csertölgy, de a Baktai-erdőben megvan.

Szlovéniai habitatok: Štanta \& Zadrgal (2016) és Gomboc S. (pers. comm.) szerint; Kopriva, 280 m, 45.78177, 13.83379; Ponikve, 325 m, 45.78986, 13.85696 12.6.2013, 17.6.2013 all (RŠ); 30.3.2014 (RŠ\&MZ); 29.6.2013; Podbreže, $380 \mathrm{~m}, 45.72658$, 13.92076. Gomboc (pers. comm.) megfogalmazásában "The association of downy oak and hop hornbeam (Ostryo carpinifoliae - Quercetum pubescentis) is a climax forest association, we find it in various positions, and it is relatively frequent."

Csehország: Lastuvka \& Liška (2011) szerint Paraboarmia viertli csehországi ismerete az 1969 és az 1992 között végzett vizsgálatok óta nem változott: „Recorded in the Bori les Forest near Valtice in southern Moravia in 1969 (Krampl et al. 1980), and occasionally abundant there in the 1970s. Very probably disappeared from the area, last recorded in 1992".

"The habitat at Valtice is ,pannonian oak forest"on sandy soils, composed dominantly by Quercus cerris - botanical opinion (entomological partly also) is, that Quercus cerris may by autochthonous here."

A szlovákiai, illetve a romániai habitatok elemzésére nem sikerült megfelelő adatokat találni, ezért erre egy későbbi munkámban visszatérek. 
Elterjedés és abundancia Magyarországon

Distribution and abundance in Hungary

Eddig 54 magyarországi lelőhelyről sikerült a fajt azonosítani (lásd az 1. táblázatot).

Egyedszáma mindenütt alacsony. A lelőhelyek tengerszint feletti magassága 100 és 600 m közé esik, döntően dombsági és részben középhegységi elhelyezkedéssel. A bizonyító példányokat 1882 és 2020 között gyüjtötték. Számos lelőhelyen (pl. Budakeszi, Budaörs, Nyíregyháza, Pécel, Simontornya, Zamárdi stb.) az elmúlt 50-60 évben nem figyelték meg, ezért monitoring vizsgálata indokolt, amelyet esősorban a nemzeti parkok igazgatóságainak kellene szorgalmaznia. Védett faj.

1. Táblázat. A magyarországi lelőhelyek listája

Table 1. List of localities in Hungary

\begin{tabular}{|l|l|}
\hline Agasegyháza & Balatonfüred \\
\hline Balf & Bisse \\
\hline Budakeszi & Budaörs \\
\hline Csarnóta & Csákvár \\
\hline Cserépfalu & Cserépváralja \\
\hline Darány & Eger (Baktai-tó) \\
\hline Felsőtárkány & Fenyőfő \\
\hline Fertőrákos & Fertőrákos (Szárhalmi-erdő) \\
\hline Gánt (Bagoly-hegy, Gránás) & Gödöllő \\
\hline Harkány (Tenkes-hegy) & Isaszeg \\
\hline Jósvafö & Kecskemét (Nyír) \\
\hline Keszthely & Köhányáspuszta (Vértes) \\
\hline Kunfehértó & Kunpeszér \\
\hline Makkoshotyka & Máriagyüd \\
\hline Nagyharsány (Szársomlyó) & Nagykovácsi \\
\hline Nagyvázsony & Nyirád \\
\hline Nyíregyháza (Baktai-erdő, Sóstói-erdő) & Odorvár (Bükk) \\
\hline Pákozd & Pécel \\
\hline Pécs (Tettye) & Pécsvárad \\
\hline Puskaporos allé (Keszthelyi-h.) & Püspökszentlászló (Hosszúhetény) \\
\hline Síkfökút & Simontornya \\
\hline Somlyóvár & Sukoró \\
\hline Süttő (Alsóvadács) & Szentlélek \\
\hline Taliándörögd & Tata \\
\hline Tusakos (Keszthelyi-h.) & Urkút \\
\hline Uzsa & Várgesztes \\
\hline Várkút & Vértesacsa \\
\hline Zamárdi & \\
\hline
\end{tabular}




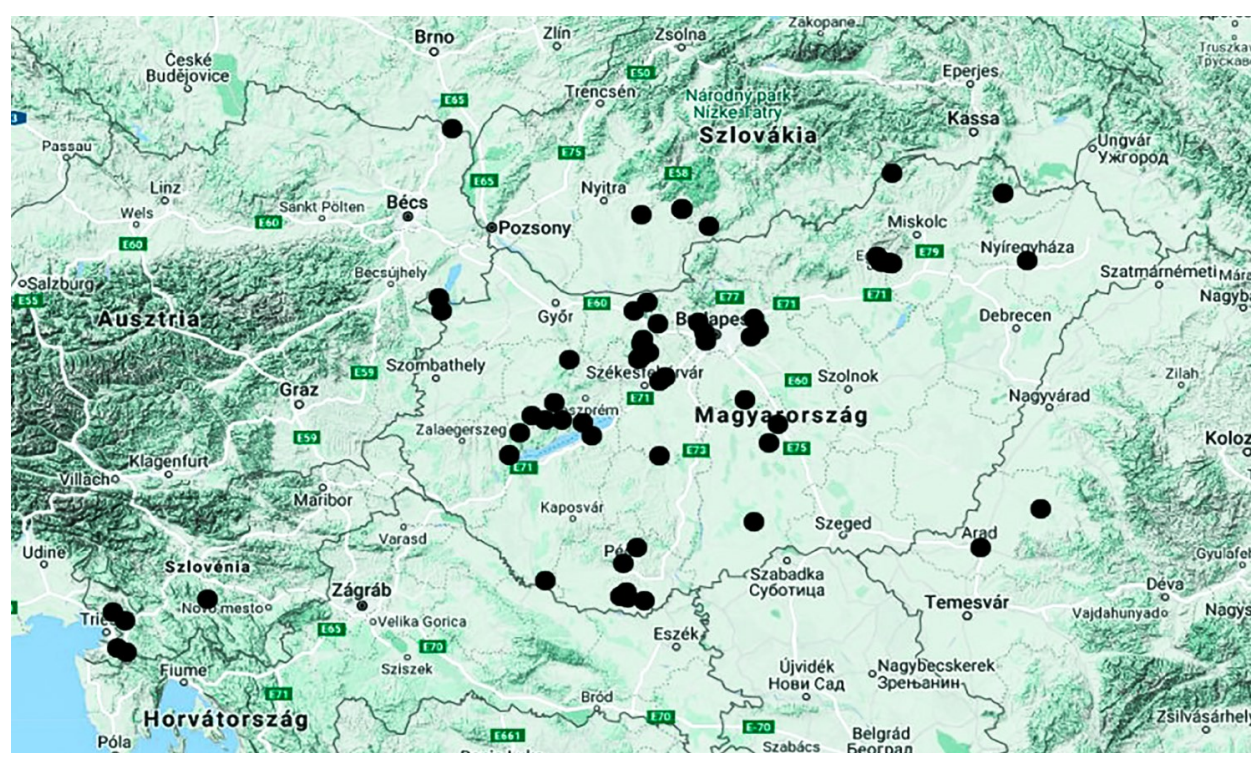

14. ábra. A Paraboarmia viertlii elterjedése Magyarországon és szomszédos országokban Figure 14. Distribution of Paraboarmia viertlii in Hungary and neighbouring countries

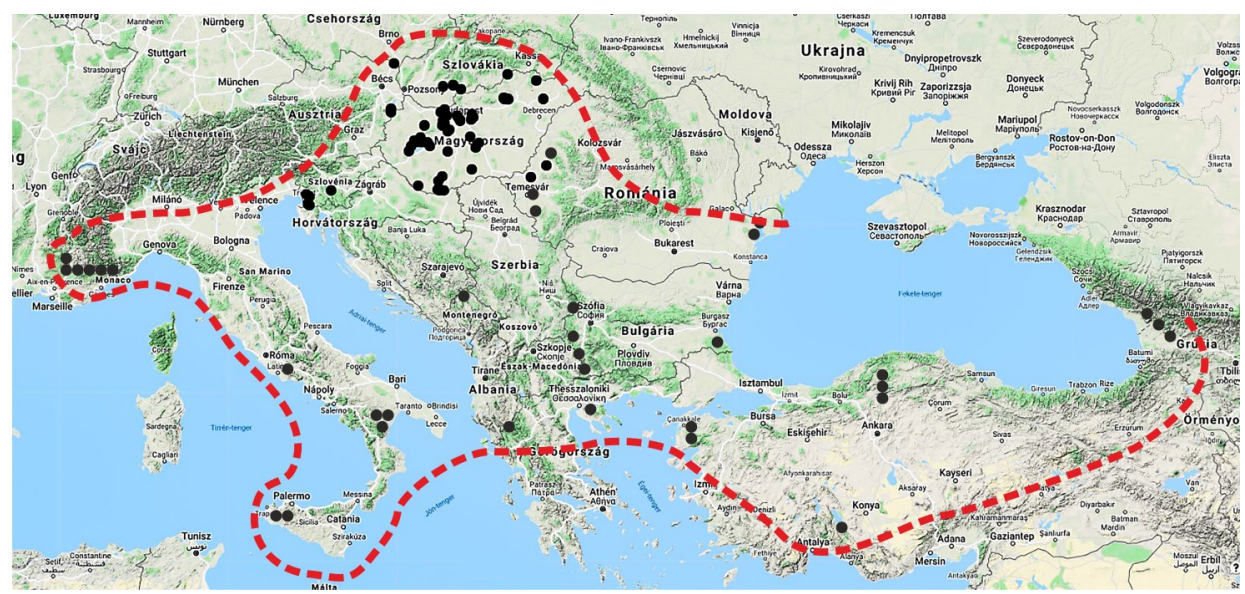

15. ábra. A Paraboarmia viertlii földrajzi elterjedése

Figure 15. Distribution of Paraboarmia viertlii

\section{Földrajzi elterjedése - Geographical distribution}

Több központú nyugat-ázsiai, európai faunaelem. Az eddig megismert chorológiai adatok alapján populáció fragmentumai a következő szekundér refugiumok területére esnek: kaszpi-, pontomediterrán-, adriatomediterrán-, dél-itáliai- és az atlantomediterrán refugiumok. A Kaukázus nyugati részétől Kisázsián, a Balkánon, a Kárpát-medencén és az Appennini-félszigeten át Provance-ig (DK-Franciaország), délen Szicíliáig gyüjtötték. Rendkívül lokális és izolált, a populációk közötti földrajzi távolság jelentős. A sík vidékektől a hegyvidékek 950 (Olaszország), és 1500 m-es magasságáig (Törökország) előfordul különféle tölgyerdő társulásokban. 


\section{Összefoglalás - Summary}

Tanulmányomban áttekintem a Paraboarmia viertli magyarországi és közép-európai kutatástörténetét. Ismertetem a faj azonosításához szükséges diagnosztikus szárny karaktereket, s hazánkban először mutatom be a hím- és a nőstény genitáliákat. Ez azért is fontos, mert az automata fénycsapdákból előkerült roncsolt példányokat így biztonságosan lehet identifikálni. A faj bionómiájáról, földrajzi elterjedésérỏl eddig igen kevés ismeretünk volt (vö. Vojnits 1980). Közlöm a hernyó azonosításához szükséges habitusképet, a preferált, illetve a potenciális habitatokat. Mintegy 70 lelőhely alapján bemutatom a $P$. viertlii magyarországi és a szomszédos országokban eddig megismert elterjedési térképét. Kiegészítettem a korábban ismert area-térképet (Müller et al. 2019).

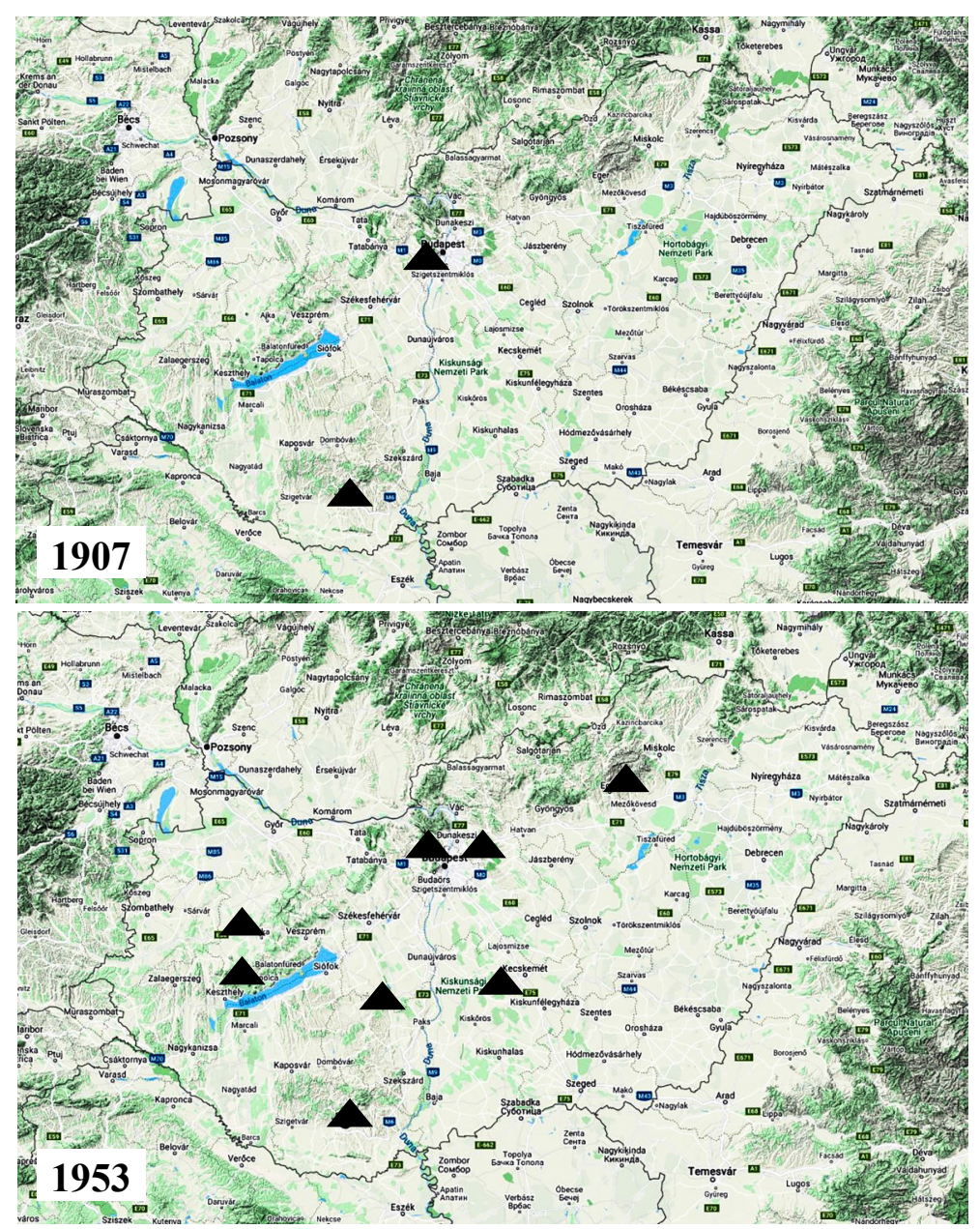

16. ábra. A Paraboarmia viertlii elterjedési adatai a 20. század elejétől a közepéig: Abafi Aigner (1907), Kovács (1953)

Figure 16. Distribution data for Paraboarmia viertlii from the early to the mid-20th century in Hungary 
Köszönet. A következő kollégáknak köszönettel tartozom a szakmai konzultációkért, a gyüjteményi adatokért, a publikációkért és a vizsgálatra megküldött példányokért: Ábrahám L. (H), Buschmann F. (H), Gomboc S. (SL), Kevey B. (H), Katona G. (H), Lastuvka Z. (CZ), Liška J. (CZ), Máté A. (H), Müller B. (D), Pastoralis G. (SK), Rézbányai L. $(\mathrm{CH})$. Az angol nyelvi korrekturáért Barry Goater (UK) barátomnak mondok köszönetet. Köszönöm a két bíráló értékes észrevételeit.

Acknowledgements. I am grateful to the following colleagues for their professional consultations, collections data, publications, and specimens send for review: L. Ábrahám (H), F. Buschmann (H), S. Gomboc (SL), B. Kevey $(\mathrm{H})$, G. Katona $(\mathrm{H}), \mathrm{Z}$. Lastuvka (CZ), J. Liska (CZ), A. Máté (H), B. Müller (D), G. Pastoralis (SK), L. Rézbányai $(\mathrm{CH})$. I thank my friend B. Goater (UK) for the English proofreading. The two reviewers provided valuable and insightful comments which greatly improved the manuscript.

\section{Irodalom - Reference}

Abafi Aigner L. 1907: Magyarország lepkéi. - Budapest, K. M. Természettudományi Társulat, 137 p., 51 tábla.

Ábrahám L. \& Uherkovich Á. 2000: A nagylepke (Lepidoptera) fauna kutatásának eddigi eredményei a Villányi-hegységben. - Dunántúli Dolgozatok, Természettudományi Sorozat 10: 309-339.

Balogh I. 1978: A Mecsek hegység lepkefaunája (Lepidoptera). - Folia Entomologica Hungarica 31(2): 41-66.

Bartha D. \& Király G. (ed.) 2015: Atlas florae Hungariae. - University of Western Hungary Press, $330 \mathrm{p}$.

Borhidi A. 2003: Magyarország növénytársulásai [Plant communities of Hungary], Akadémiai Kiadó, Budapest, 610 p.

Borhidi A., Kevey B. \& Lendvai G. 2012: Plant communities of Hungary. - Akadémiai Kiadó, Budapest, 544 p.

Bölöni J., Molnár Zs. \& Kun A. (eds.) 2011: Magyarország élöhelyei [Habitats of Hungary] | Vegetációtípusok leírása és határozója | ANÉR 2011. - MTA Ökológiai és Botanikai Kutatóintézete, Vácrátót, 441 p.

Fazekas I. 1979: Vizsgálatok a Keleti-Mecsek nagylepkefaunáján III. A püspökszentlászlói arborétum és környékének nagylepkéi (Lepidoptera) | Investigations on the macrolepidoptera fauna of East Mecsek Mts. III. Arboretum of Püspökszentlászló and its environs (Lepidoptera). - Janus Pannonius Múzeum Évkönyve 23: 71-86.

Fazekas I. 2005: A Mecsek hegység védett lepkefajai (Lepidoptera)| Schutz der Lepidopterenarten im Mecsek Gebirge, Süd Ungarn. - Folia comloensis 14: 3-44.

Fazekas I. 2006: A Mecsek nagylepke faunája (Lepidoptera) | Die MacrolepidopterenFauna des Mecsek-Gebirges in Süd-Ungarn. - Folia comloensis 15: 239-298.

Forster W. \& Wohlfahrt Th. 1981: Die Schmetterlinge Mitteleuropas | Spanner (Geometridae). - Frankckh'sche Verlagshandlung Stuttgart, 312 p., Tafel 1-26.

Gyulai P., Uherkovich Á. \& Varga Z. 1974: Újabb adatok a magyarországi nagylepkék elterjedéséhez | Neuere Angaben zur Verbreitung der Gross-Schmetterlinge (Macrolepidoptera) Ungarns. - Folia Entomologica Hungarica 27: 75-87.

Habeler H. 2011: Paraboarmia viertlii (Bohatsch, 1883), eine für Slowenien neue Geometridae (Lepidoptera: Geometridae). - Acta Entomologica Slovenica 19(2): 199_ 200.

Hausmann A. 2001: The Geometrid Moths of Europe | Volume 1. - Apollo Books, Stenstrup, $282 \mathrm{p}$. 
Horváth B. 2016: A Soproni-hegyvidék gyertyános-kocsánytalan tölgyes erdeiben elöforduló éjszakai nagylepkék állatföldrajzi jellemzői. - Erdészettudományi Közlemények 6(2): 151-159.

Juhász M. 1983: A Barcsi Borókás Tájvédelmi Körzet magasabbrendü növényei. - Dunántúli Dolgozatok Természettudományi Sorozat 3: 35-46.

Kevey B., Papp L. \& Lendvai G. 2017: A Nyírség gyertyános-tölgyesei (ConvallarioCarpinetum Kevey 2008). - Botanikai Közlemények 104(1): 147-164 + Elektronikus mellékletek: E1-E3 táblázat.

Kovács L. 1953: A magyarországi nagylepkék és elterjedésük | Die Gross-Schmetterlinge Ungarns und ihre Verbreitung. - Folia Entomologica Hungarica 6(2): 77 162.

Krampl F. 1994: Paraboarmia gen. n. for Boarmia viertlii Bohatsch, 1883 (Lepidoptera, Geometridae). - Folia Heyrovskyana 2/8: 89-100.

Krampl F., Marek J. \& Novák Z. 1980: Beitrag zur Lepidopterenfaunistik der Tschechoslowakei. - Acta faunistica entomologica Musei nationalis Pragae 16: 89-105.

Lastuvka Z. \& Liška J. 2011: Annotated checklist of moths and butterflies of Czech Republik (Insecta: Lepidoptera). - Biocont Laboratory spol. s r. o. Brno, 146 p.

Müller B., Erlacher S., Hausmann A., Rajaei H., Sihvonen P. \& Skou P. 2019: The Geometrid Moths of Europe, Vol. 6, Ennominae II. - EJ Brill, Leiden, 906 p.

Pastorális G. \& Szeőke K. 2018: A Vértes hegység lepkefaunája | Lepidoptera fauna of Vértes Mountains (Hungary) (Lepidoptera). - e-Acta Naturalia Pannonica 16: 1-73. https://doi.org/10.24369/eANP.2018.17.1

Petrich K. 2001: A Velencei (sic!) táj lepkevilága. - Mezőgazdasági Szaktudás Kiadó, Budapest, $305 \mathrm{p}$.

Rakonczay Z. 1989: Vörös könyv | A Magyarországon kipusztult és veszélyeztett növény- és állatfajok (Hungarian Red Data Data Book). - Akadémiai Kiadó, Budapest, 359 (360) p.

Reiprich A. \& Okáli I. 1989: Dodatky k Prodromu Lepidopter Slovenska 3. zväzok. VEDA vydavatel'stvo Slovenskej akadémie vied Bratislava, $139 \mathrm{p}$.

Rézbányai L. 1972: Vizsgálatok a Balaton délkeleti (Balatonszabadi-Zamárdi) partvidékének nagylepkefaunáján (Lep.). - Folia Entomologia Hungarica (Series nova) 25: 229-252.

Stanta R., Zadrgal M. 2016: Contribution to the knowledge of Lepidoptera fauna of the karst. - Acta Entomologica Slovenica 24(2): 69-150.

Varga Z. (ed.) 2010: Magyarország nagylepkéi | Macrolepidoptera of Hungary. - Heterocera Press Budapest, 253 p.

Wanke D. \& Rajaei H. 2018. An effective method for the close up photography of insect genitalia during dissection: a case study on the Lepidoptera. - Nota Lepidopterologica 4(1): 219-223.

Viertl A. 1898: Két Geometra-hernyó. - Rovartani Lapok 5: 79-80.

Vojnits A., Ács E., Bálint Zs., Gyulai P., Ronkay L. \& Szabóky Cs. 1993: The Lepidoptera Fauna of the Bükk National Park. In Mahunka S. \& Zombori L. (eds.): The fauna of the Bükk National Park I. - Magyar Természettudományi Múzeum, Budapest, pp. 157-318.

Zagyvai G. \& Bartha D. 2015: A nyírségi erdőtömbök és környezetük tájtörténeti vizsgálata. - Tájökológiai Lapok 13(1): 59-72. 